\title{
USING STRUCTURAL EQUATION MODELING (SEM) TO CONSTRUCT THE MODEL FOR CULTIVATING EMPLOYEE EXCELLENCE THROUGH ENGAGEMENT, ENABLEMENT, AND EMPOWERMENT
}

\author{
Iman Permana \\ MBATech Study Program, Faculty of Business, President University, Indonesia \\ Email: iman.permana@president.ac.id
}

\begin{abstract}
This study quantitatively assessed the model of Employee Excellence with predictor constructs of Employee Engagement, Enablement, and Empowerment. The analyses utilized Structural Equation Modeling (SEM) with latent variables. The measurement model for the predictor variables used formative indicators, therefore, this study used Partial Least Square (PLS)-SEM. The research focused on eight manufacturing companies in Indonesia, with foremen as the unit of analysis, totaling as many as 257 respondents. Research findings revealed that each predictor construct has a key driver: Psychological Capital was found to be the key driver of Employee Engagement, Infrastructure for Data Sharing (which was later reconfirmed as Knowledge Management) was the key driver of Employee Enablement, and Transformational Leadership was the key driver of Employee Empowerment. The study also revealed that Employee Engagement, Enablement, and Empowerment altogether related positively and significantly with Employee Excellence. The research findings provide empirical basis for prioritizing strategic actions on the most important factors for affecting employee engagement, enablement, and empowerment, in order to foster employee excellence.
\end{abstract}

Keywords: PLS-SEM, employee excellence, engagement, enablement, empowerment

\begin{abstract}
ABSTRAKSI
Studi ini secara kuantitatif menelaah model Keunggulan Pegawai dengan predictor constructs Keterlibatan, Keberdayaan, dan Keberwenangan Pegawai. Analisisnya menggunakan Structural Equation Modeling (SEM) variabel-variabel laten. Model pengukuran untuk variabel predictor menggunakan indikator formatif, dan oleh karena itu, studi ini memakai Partial Least Square (PLS)-SEM. Riset berfokus pada delapan perusahaan manufaktur di Indonesia, dengan foremen sebagai unit analisis, berjumlah sebanyak 257 responden. Temuan-temuan riset mengungkapkan bahwa setiap predictor construct mempunyai penggerak utama: Psychological Capital merupakan penggerak utama Keterlibatan Pegawai, Infrastruktur untuk Berbagi Data (yang kemudian dikonfirmasi ulang sebagai Knowledge Management) merupakan penggerak utama Keberdayaan Pegawai, dan Kepemimpinan Transformasional merupakan penggerak utama Keberwenangan Pegawai. Studi ini juga mengungkapkan bahwa Keterlibatan, Keberdayaan, dan Keberwenangan Pegawai secara bersama-sama berkorelasi positif dan signifikan terhadap Keunggulan Pegawai. Temuan-temuan riset memberikan dasar bagi pemrioritasan tindakantindakan strategis pada faktor-faktor yang paling penting untuk mempengaruhi keterlibatan, keberdayaan, dan keberwenangan pegawai, dalam upaya untuk menumbuhkembangkan keunggulan pegawai.
\end{abstract}

Kata-kata kunci: PLS-SEM, keterlibatan, keberdayaan, keberwenangan, keunggulan pegawai 


\section{A. INTRODUCTION}

We are often faced with a question: what is required for organizations to achieve performance excellence? To a certain extent, it depends on the environment and circumstances facing the specific organization: what is most important for one organization may differ for another because of differences in market, core competencies, and other key factors, but one thing is certain: because the people in an organization make the organization what it is, the real power of an organization is its ability to create excellence among its people (Senge 2015; Liker and Meier 2007). This ability is what differentiates an organization from the others, and as a result, will build strong competitiveness in the ever-changing business dynamics.

Peter Senge (2006) argued that the organizations that would excel in the future would be those that discover how to tap people's commitment and capacity at all levels of the organizations. Doug Conant, CEO of Campbell's Soup, once said that to win in the marketplace we must first win in the workplace. There is no better way to measure the strength of a company than by the excellence that its employees make every day. The more the excellence delivered by its employees, the stronger the organizational excellence will be. This is how we should now view the power and strength of an organization. The question, then, is: how to bring about employee excellence?

Permana, Tjakraatmadja, Larso, and Wicaksono (2015) in their paper introduced a new model in building and sustaining employee excellence through the constructs of employee engagement, enablement, and empowerment. Their study identified important drivers to be included in the models of employee engagement, enablement, and empowerment. As a furtherance of their study, the research questions of this paper are: "How do engagement, enablement and empowerment affect employee excellence?", and "How can we grow the key drivers of engagement, enablement, and empowerment to affect employee excellence?"

Building on these research questions, this study was conducted with the main objective of (1) quantitatively analyzing the theory development of the effect of employee engagement, enablement, and empowerment on employee excellence, (2) quantitatively analyzing the key drivers of engagement, enablement, and empowerment, and how they predict employee excellence, and (3) assessing practical and managerial implications to provide suggestions for prioritizing employee development.

\section{B. LITERATURE REVIEW}

Numerous literatures, such as Senge (2006, 2015) and Liker \& Meier (2007), emphasized 
the crucial importance of people as the building blocks of organizational excellence. Having excellent employees can help ensuring the organization's success and survival. Today, the workplace is changing from autocratic, low involvement, and low commitment cultures to cultures that put emphasis on empowerment and involving the workforce as business partners.

In associating employee excellence with work performance, many previous studies related employee performance with employee engagement alone, or with employee engagement and enablement, or with employee empowerment alone. No previous studies were found to relate employee excellence with all the three constructs altogether: engagement, enablement and empowerment.

Kahn in his 1990 paper was one of the first to theorize about work-related engagement. He described engaged employees as being fully physically, cognitively, and emotionally connected with their work roles. Macey, Schneider, Barbera, and Young (2009) defined employee engagement as 'an individual's sense of purpose and focused energy, evident to others in the display of personal initiative, adaptability, effort, and persistence directed toward organizational goals.' It shows the extent to which an employee is motivated to contribute to organizational success and is willing to apply discretionary effort to accomplishing tasks that are important to the achievement of organizational goals (Wiley, Kowske, and Herman, 2010). Further literature review revealed that employee engagement related to how people perceive their tangible rewards (Wilson, 2007; Binhu, 2012). Newman, Joseph, and Hulin (2010) showed engagement construct that underlays job satisfaction. Shahnawaz and Jafri (2009) explored how psychological capital as introduced by Luthans, Yousseff, and Avolio (2007) had some roles in influencing employee engagement through organizational commitment.Schaufeli, Bakker, and Salanova (2006) found that engagement and age were so weakly related that it could hardly be considered meaningful.

Employee enablement was first conceptualized by Adler and Borys in 1996. An enabling work environment is defined as one that provides the tools and processes to deal with employee frustrations (Colenbaugh and Reigel, 2010). Towers-Watson report (2016) stated that "enablement means that organization must provide, at minimum, well-functioning equipment, the necessary supplies, effective work processes, and clear direction from supervisors." Choo and Neto (2010) revealed that supportive working environment correlated with how an employee perceives how collaborative is the organization's working environment.A study by the Economist Intelligence Unit showed a positive correlation between employees' degree of enablement and self-reported financial performance (Wright, 2008).

Employee empowerment is about the authority to make decisions (Osborne and Plastrik, 


\section{Volume : 6 Nomor : 1 Maret 2021}

2000). This sense of having authority can serve as a strong motivator for employees to excel. A study by Arquisola and Ahlisa (2019) found that employees are strongly motivated to develop themselves when they feel the development will result in having higher authority and responsibility. In this context, empowerment translates into how much employees are informed and are involved in decisions that affect their work and the work of their organization. Thus, empowerment may not live well in an authoritarian style of management. Unlike the authoritarian style, transformational leadership is found to closely correlate with the feeling of empowerment (Avey, Hughes, Norman, and Luthans, 2007). According to Ismail, Mohamed, Sulaiman, Mohamad, and Yusuf (2011), transformational leadership related to empowerment and that this relationship positively and significantly correlated with organizational commitment. Avey et al. (2007) revealed that empowerment also related to positive psychological capital. Empowerment was referred to as individual sense that they 'have a choice in initiating and regulating actions.' Empowerment is 'the degree to which an individual can influence strategic, administrative or operating outcomes at work.'

Previous studies found in literature review researched engagement alone, or engagement and enablement, or empowerment alone, in relation with employee excellence. No previous study could be found that assessed all these three constructs altogether with regards to employee excellence.The work by Permana et al. (2015) is considered as one of the first to examine the roles of all these three constructs on employee excellence. Synthesizing from various resources in their literature review, they defined employee engagement as: "the intensity of employees' emotional connection (i.e. attachment) that they feel for their organization, which influences them to exert greater discretionary effort (i.e. extra effort) committed to achieving their work goals." Employee enablement was defined as: "the extent to which employees feel they are provided with what they need to do their jobs well and are provided with an environment in which they feel comfortable to perform to the best they can be." Employee empowerment was defined as: "the extent to which employees feel they are given problem-solving and decisionmaking authority to take responsibility for using the organization's resources to achieve results."

Literature offers various definitions and descriptions of excellence. Organizations traditionally have relied heavily upon financial measures to evaluate their performance, value and "health". However, such "hard" metrics as profitability, revenues, return on capital, cash flow and various margins are inadequate for developing strategies and implementation plans for the future. Proactive leaders have come to rely more and more upon the "soft" numbers to best predict direction and action planning. Many studies argued that it was more effective for business leaders to examine the soft numbers for direction. 
This premise is also true at individual level. Avolio and Luthans (2006) suggested that an excellent employee should excel not only toward work, but also toward customers (internally and/or externally) and toward people (subordinates, peers, superiors, and others). They argued that the first question to ask should be "what is right for the customers?". If the customer thinks that a particular outcome is not valuable, then it is not. The next question to ask is "what is right for the company?". The outcomes we define for our people should be in line with the company's current strategy. The last question to ask is "what is right for the people?"

Based on the above arguments, this paper defines employee excellence in three dimensions: excellence toward customer, excellence toward people, and excellence toward tasks or work. The study by Permana et al. (2015) proposed a framework for developing sustainable employee excellence through the constructs of employee engagement, enablement, and empowerment. The study also identified important drivers that predict employee engagement, enablement, and empowerment.

\section{RESEARCH METHOD}

This study was based on the model shown in Figure 1. The constructs of Engagement, Enablement, and Empowerment are treated as latent exogenous variable, with the drivers as the formative (i.e. causal) measures. The construct of Employee Excellence is treated as latent endogenous variable, with its reflective manifests of Safety, Productivity, Quality, Customer Service, and Leadership. These manifests are selected based on top five most-desired criteria of excellent employees found in the sampled companies through evidence-based interviews.

This study focused on select manufacturing companies in Indonesia, with foremen as the unit of analysis. Foremen are leaders at the shop floor level, who interact intensively with the labor force, bridging management directives and production floor operational executions. The respondents were foremen at eight manufacturing companies in Indonesia, four of which were foreign direct investment multinational consumer goods companies, while the other four were local or national companies. Their lines of businesses were fashion dolls, garments, electronics, packaging goods, and consumer goods. Employee populations ranged from a few hundred to several thousand people, with the number of foremen ranged from 12 people to 110 people. There were 257 foremen researched, which represented $53 \%$ of the total foremen in the eight subject companies.

The model in Figure 1 shows that engagement, enablement, and empowerment are latent independent variables, measured through the scores of the drivers (X1 through Z4). The scores were obtained from the responses of survey questions, gathered from the 257 respondents. 
Questions were developed to measure the drivers of each construct. Each driver had two measures, except for transformational leadership and psychological capital which each had four elements as adapted from Luthans, Yousseff, and Avolio (2007). Using a 5-point Likert scale, the questionnaire contained the list of questions as shown in Figure 2. Asterisk indicates question with reversed coding when analyzed.

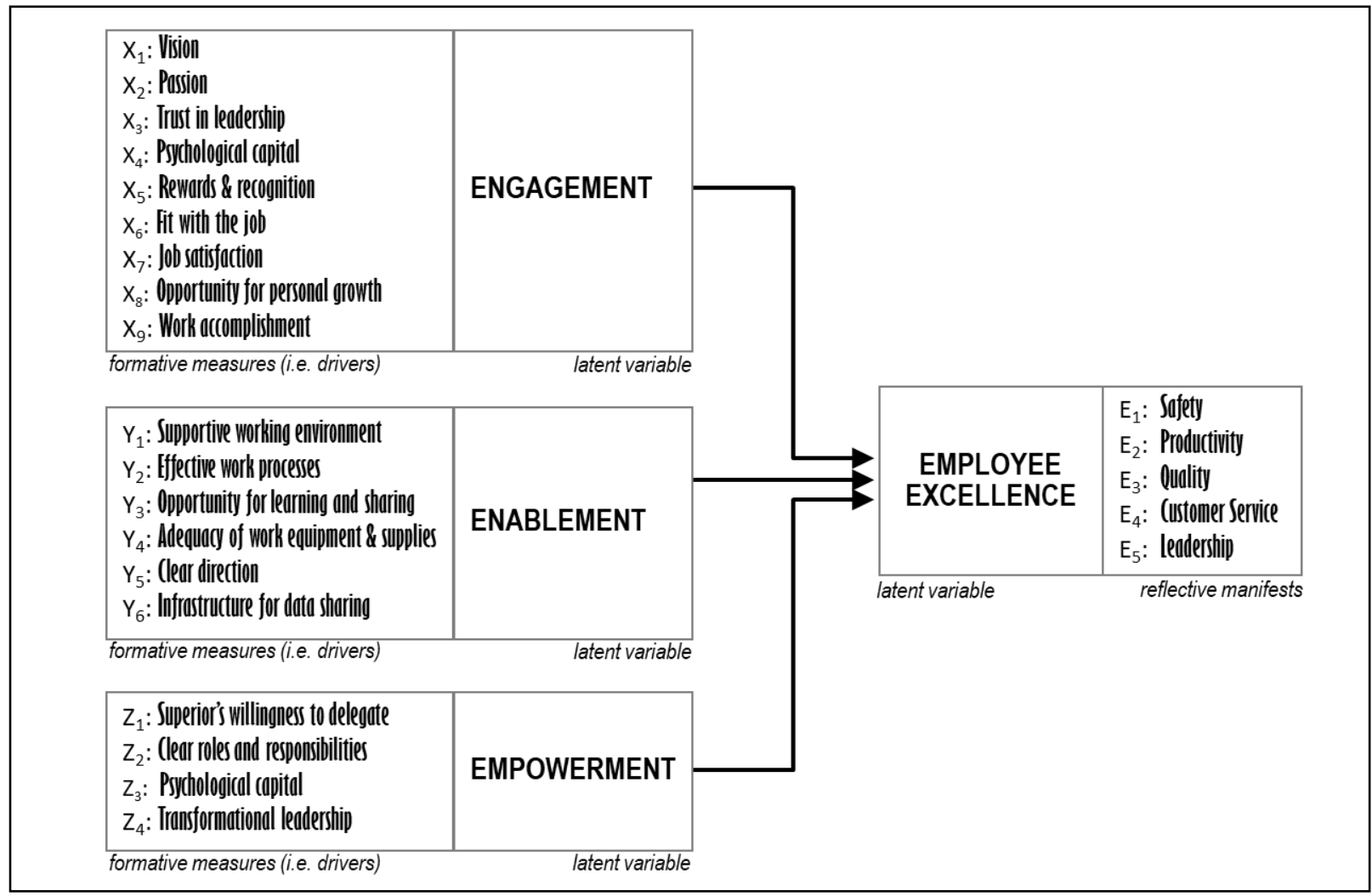

Figure 1. Employee Excellence Mode

In the questionnaire form, the questions were ordered in such a way that each measure of each driver was not placed adjacent to each other to ensure unbiased responses. Three sessions of pilot tests were conducted to check for respondents' understanding on the questionnaire items and to determine the suitability of the questionnaire items for the study context. The actual survey sessions were conducted in a room of maximum 20 people/batch, facilitated by a Human Resources personnel. All responses were checked for completeness before dismissing the respondents from the room. This way, we could ensure complete responses and $100 \%$ response rate from the 257 respondents.

As previously mentioned, employee excellence was scored using 5 manifests: safety, productivity, quality, customer service, and leadership performances. Safety performance was obtained from the safety records achieved in the respondents' manufacturing lines of responsibility. Productivity performance was obtained from the respondents' manufacturing 
lines' output per unit of time. Quality performance was obtained from the respondents' manufacturing lines' defect rate per million of products produced. These performances were scaled from 1 to 5 , with 1 being the lowest of the respondents' achievements, 5 being the achievement of the targeted goals in their key performance indicators, and the in-betweens were scaled linearly. Customer service performance was obtained from a 5-point Likert scale evaluation feedback filled out by the respondents' next-in-process customers. Leadership performance was obtained from a 5-point Likert scale 3600-degree feedback from the respondents' superior, peers, and subordinate.

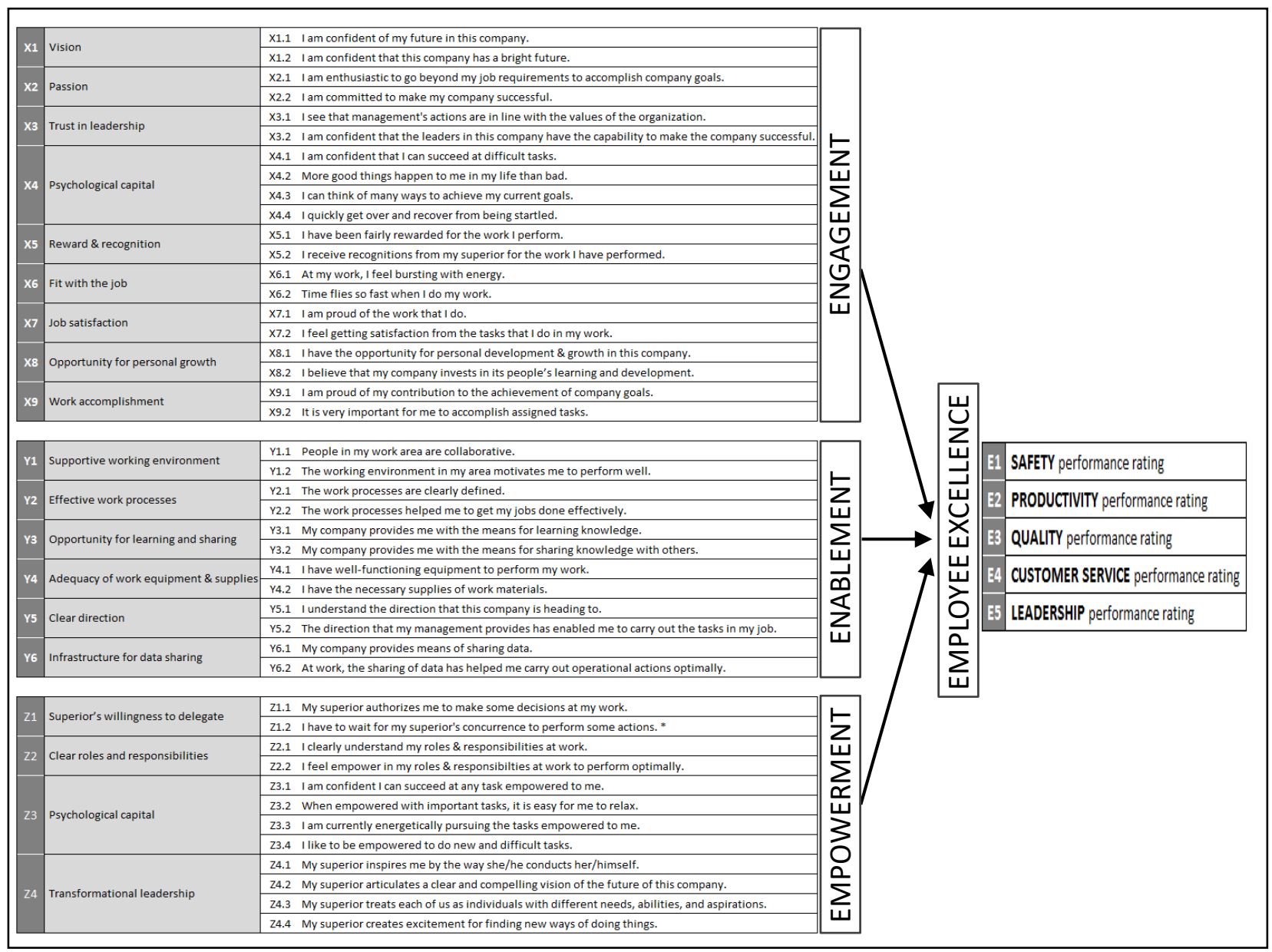

Figure 2. Measures and Manifest of Employee Excellence Model

In analyzing the collected data, the study performed both descriptive and inferential statistics. The former provides a general overview of the responses, with the objective of exploring the data to understand the nature and characteristics of the data and to help in ensuring the appropriate analyses or procedures in hypothesis testing. The latter was conducted to infer relevant information with regards to the results. The study used Structural Equation Modeling (SEM) for the inferential statistics to analyze the predictive relationship of the variables in the 
model. The SEM is distinct from a path or regression model in that it hypothesizes that crucial variables (such as employee engagement, enablement, empowerment, and employee excellence researched in this study) are not directly observable and are better modeled as latent variables than as observable ones. The SEM was assessed using SmartPLS software version 3. The model was analyzed and interpreted into two stages sequentially. First was the assessment and refinement of the measurement model, followed by the assessment and evaluation of the structural model.

\section{RESEARCH RESULTS AND DISCUSSION}

The collected data were analyzed for the descriptive analysis by using the Statistical Package for Social Sciences (SPSS) software version 22. The study first looked at the frequency testing. The number of valid responses was verified.Since the data were obtained from eight different companies, analysis of variance was needed to check whether the data could be analyzed as one population. The study analyzed the differences among the sampled companies to see if there was any significant difference between companies on some questionnaire items that necessitated individual company's analysis. One-way ANOVA (Analysis of Variance) was conducted with post-hoc multiple comparisons using Scheffé. Pairwise multiple comparison was conducted to test the difference between each pair of means and yielded a matrix to indicate significantly different group means at a significance level of 0.05. Theresults show significance level of greater than 0.05. This indicated that the responses from the eight companies were not significantly different, and thus, they could be combined as one sampled population in further.

The study then examined the pattern of correlation or covariance between the observed measures by performing factor analysis to check if the proposed factor structures were indeed consistent with the actual data. This was run using the principal components extraction method with Varimax rotation, an orthogonal rotation method that minimizes the number of factors that have high loadings on each factor. Factor Analysis assumed that the data are normally distributed, and observations should be independent (uncorrelated with each other). To check for normality, this study used skewness and kurtosis. Kline (2005) argued that absolute value of skewness and kurtosis should not be greater than 3.0 and 10.0, respectively. According to Coakes and Steed (2007), data were considered normal if skewness was between -1 to +1 and kurtosis was between -2 to +2 . Hair et al. (2010) and Bryne (2010) argued that data was considered normal if Skewness was between -2 to +2 and Kurtosis was between -7 to +7 . The study showed that all the skewness fell between -1 and +1 , and all the kurtosis fell between -2 and +2 . This indicated that the data were all normally distributed. 


\section{Volume : 6 Nomor : 1 Maret 2021}

The study subsequentlyexamined if the observations of a construct are independent ofeach other. For this purpose, the study ran reliability analysis. Reliability is the degree to which an assessment tool produces stable and consistent results. The study computed the most commonly used type of internal consistency reliability, Cronbach's coefficient alpha. The study found that the cronbach's alphas were within the acceptable range and that none of the correlation coefficients of the items between different constructs were larger than 0.20 , which indicated that inter-construct correlations were considerednegligible. Thus, the study proceeded with the factor analysis using the principal components extraction method with Varimax rotation. This method is most useful to reduce a relatively large number of variables into a smaller set of variables that still captures the same information (Leech et al. 2005). This approach allows the computation to determine which, of a fairly large set of items, "hang together" as a group. It essentially aims to simplify subsequent analysis of the data.

The Kaiser-Meyer-OIkin (KMO) measure was needed to test whether enough items were predicted by each factor. The Bartlett's test should be significant to provide a reasonable basis for factor analysis. The study found that KMO measures were within the acceptable range of .704 for X, .623 for Y, and .803 for Z, which indicated sufficient items for each factor. The Barlett's Tests of Sphericity were less than 0.05 , which indicated that the correlation matrix was significantly different from an identity matrix, in which correlations between variables were all zero, and thus, and could be used in further analysis.

The Total Variance Explained produced from the analysis showed how the variance was divided among the possible factors. Leech et al. (2005) stated that a factor should have eigenvalues (a measure of explained variance) larger than 1.0 to be useful.The study found that eight (of the 20) factors of $\mathrm{X}$ had eigenvalues greater than 1.0, six (of the 12) factors of $\mathrm{Y}$ had eigenvalues greater than 1.0, four (of the 12) factors of $\mathrm{Z}$ had eigenvalues greater than 1.0.

Since the study used Varimax rotation (orthogonal rotation), this means that the final factors would be as uncorrelated as possible with each other. As a result, we could assume that the information explained by one factor was independent of the information in the other factors. We rotated the factors so that they were easier to interpret. Rotation made it so that, as much as possible, different items were explained or predicted by different underlying factors, and each factor explained more than one item. Loadings produced from an orthogonal rotation were correlation coefficients of each item with the factor, so they ranged from -1.0to +1.0 . A threshold for high loadings may be set as low as 0.30 or as high as 0.50 (Leech et al., 2005). Setting the threshold lower than 0.30 or higher than 0.50 would be very unusual. According to Tabachnick and Fidell (1996), the minimum value for a good factor loading analysis is 0.50 . 
Size sorting and suppressing small coefficients with a thresholdof 0.50 to pick high loading (ie. omit loading of less than 0.50 to improve clarity) showed that -- after rotation -- the computation had grouped the 20 questions of engagement drivers (items X1.1 to X9.2) into eight overlapping groups of items, each of which had a loading of larger than $|0.50|$. Likewise, the 12 questions of enablement drivers (items Y1.1 to Y6.2) were grouped into six overlapping groups of items, and the 12 questions of empowerment drivers (items Z1.1 to Z4.4) were grouped into four overlapping groups of items. The content of the items that had high loadings from each factor suggested that they fitted together conceptually (i.e. fell within the same construct), as shown in Table 1.

Table 1. Rotated Component Matrices
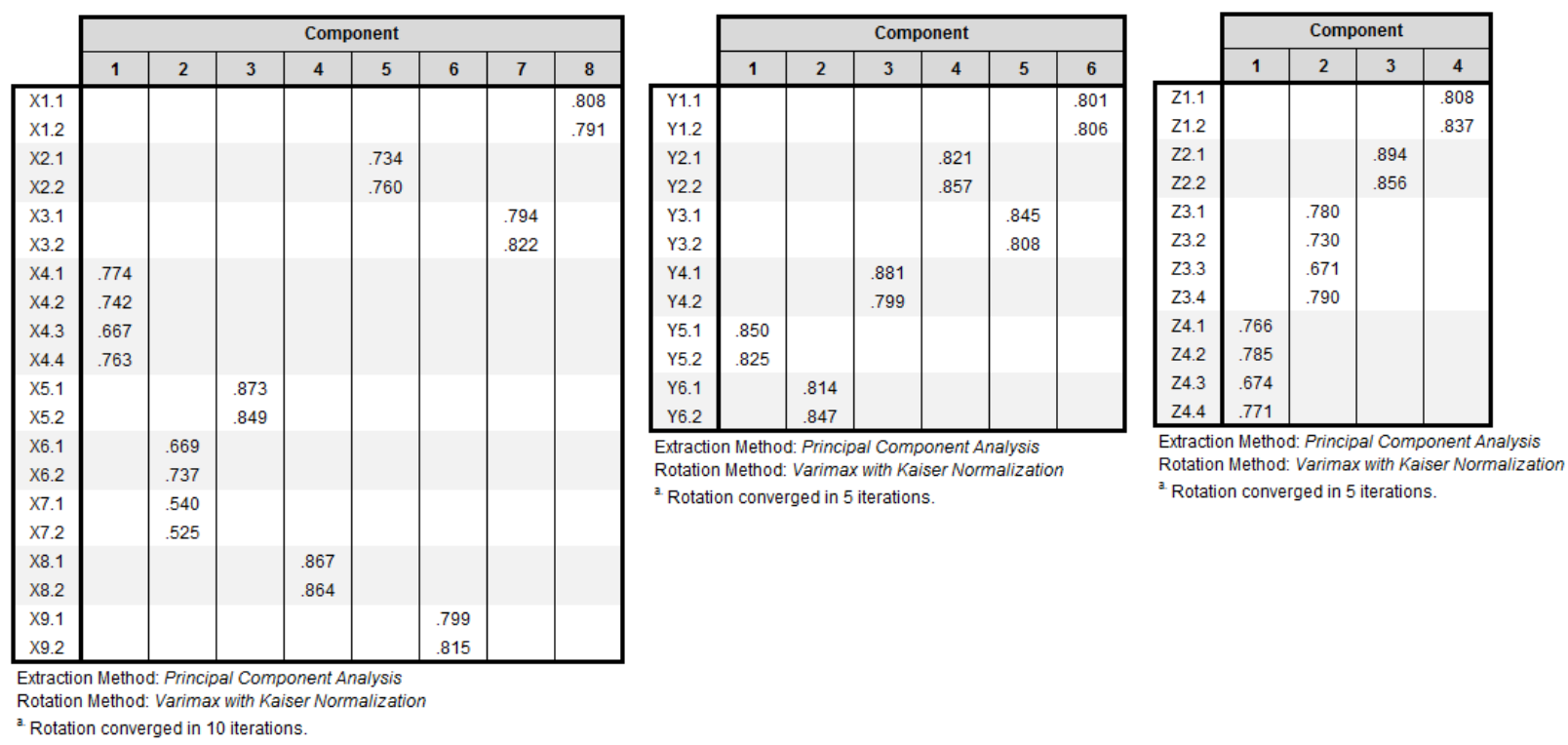

Researchers usually give names to each component in such a fashion that the name indicates the items that have high loadings in the overlapping groups. Often, a researcher aggregates (adds or averages) the items that define (i.e. have high loadings for) each componentand uses this composite variable in further research (Leech et al. 2005). In this study, the score for each component was obtained by averaging the scores of the items of the overlapping groups shown in Table 1, and each component was named according to the content of those items.Table 2 shows the complete naming of the components and where their scores come from.

For better clarification and to maintain four-digit coding, the dependent variable manifests were named descriptively as follows: manifest E1 was named SFTY (safety), manifest E2 was names PROD (productivity), manifest E3 was named QLTY (quality), manifest E4 was named SERV (customer service), and manifest E5 was named LEAD (leadership). 
This study then continued with the inferential analysis by adopting SEM with latent variables to analyze the predictiveness of the relationship of the variables in the model. Wong (2013) and Hair et al. (2011) explained that there were two parts to SEM: the "Measurement Model" (the outer model) and the "Structural Model" or a "Path Model" (the inner model). The Measurement Model is where we test the relationship of an unobserved variable (a "latent variable" or a "construct") with a set of observed variables ("indicators" or "measured variables"). The Structural Model shows the relationships (paths) between the latent constructs. In the structural model, we distinguished between exogenous (latent independent) and endogenous (latent dependent) constructs.

Table 2. Components' Naming and Scoring after Compositing

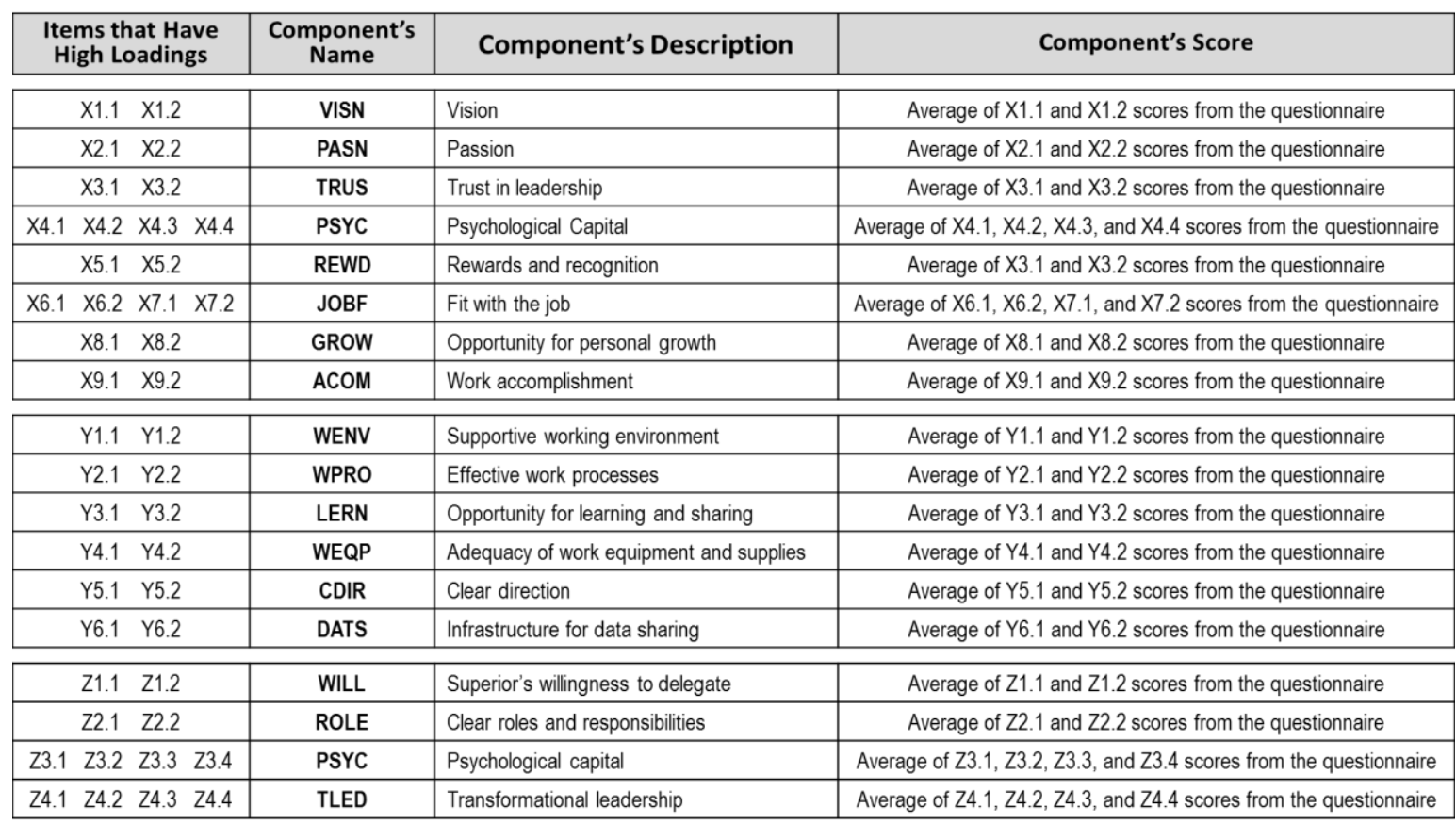

There are two distinct approaches to SEM: Covariance-Based SEM (CB-SEM) and Partial Least Squares SEM (PLS-SEM). The CB-SEM allows us to test how well the model fits the data. It aims at minimizing the difference between the model covariance matrix and the sample covariance matrix which is obtained from the observed manifest indicators. The PLSSEM makes use of a series of ordinary least squares (OLS) regression. It aims at maximizing the variance explained for the endogenous constructs (dependent latent variables).

This study used PLS-SEM, conducted using SmartPLS software version 3. PLS-SEM was chosen considering that it handles both formative indicators and reflective indicators, whereas CB-SEM did not permit this. This ability enabled the designation of the type of relationship that we believed to exist between the causal indicators and the latent constructs. Wold (1981) specifically advised that PLS-SEM was not suitable for confirmatory testing, rather 
should be used for prediction and the exploration of plausible causality. PLS-SEM did not assume multivariate normality, whereas the CB-SEM did; and being a nonparametric procedure, the problem of multicollinearity was not an issue (Bido2006). PLS's requirement on sample size was lower than CB-SEM (Chin and Newsted1999; Westland2007). Sample size requirements were equal to the larger of: 10 times the number of indicators on the most complex formative construct, or 10 times the largest number of independent constructs leading to an endogenous construct (Bido2006; Westland2007). After refinement from factor analysis, this study had 18 indicators on its formative measurement model, and thus, required at least 180 samples. Our 257 samples should therefore fit the sample size requirement of PLS-SEM. Based on the results of compositing from factor analysis (principal component analysis), the researcher modeled the theoretical concept for this study as shown in Figure 3.In this model, the drivers (VISN, PASN, TRUS, etc. until TLED) were the observed measures (formative indicators) of the unobserved latent independent variables:Engagement, Enablement, and Empowerment.

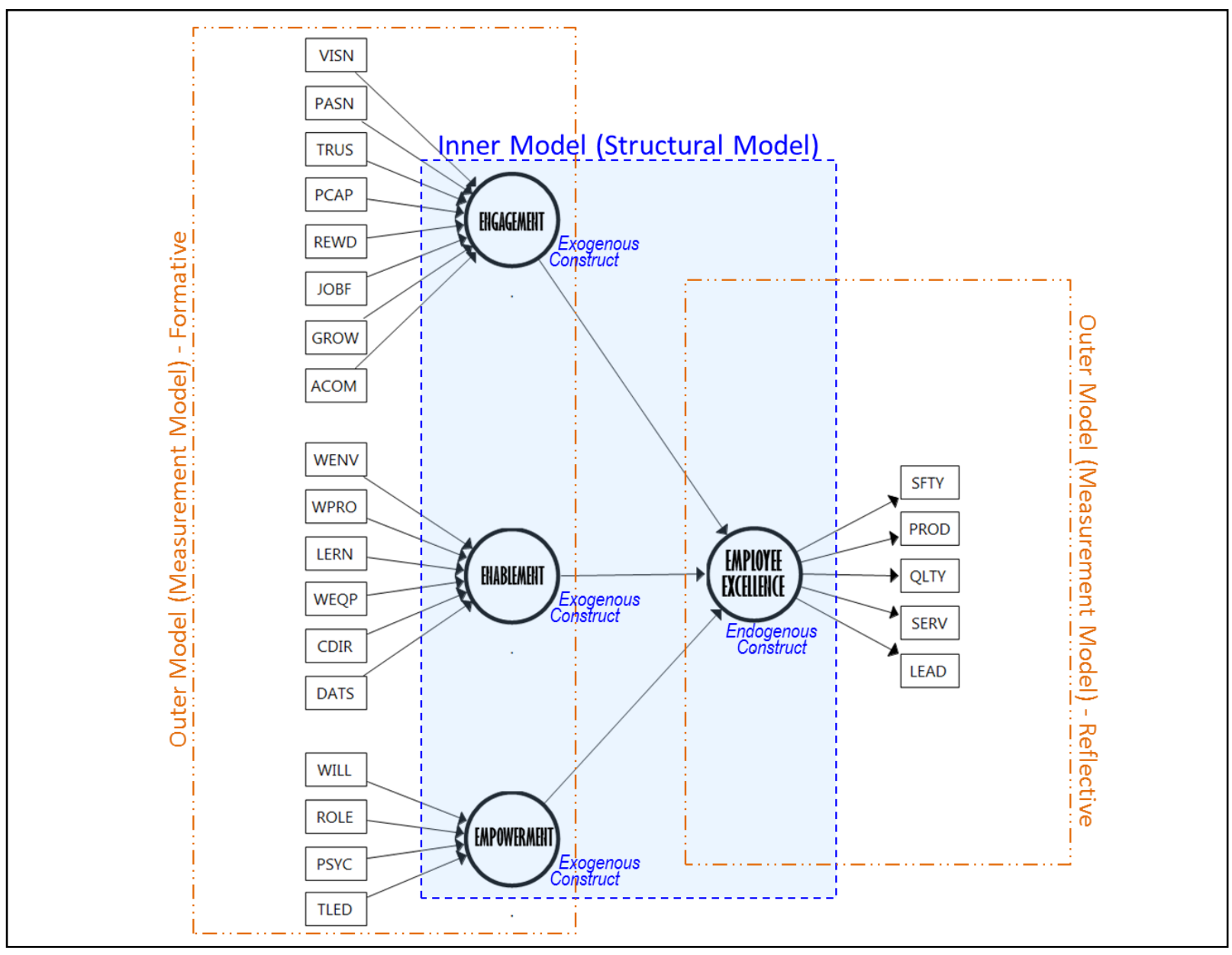

Figure 3. The Hypothesized Model of the Study

Hair et al. (2011) explained that in a formative measurement model, such as shown in 
Figure 3, indicators (i.e. the drivers) represented the latent construct's (potentially) independent causes, and thus, they did not necessarily correlate highly. Formative indicators were assumed to be error-free (Edwards and Bagozzi2000). Consequently, the concepts of internal consistency reliability and convergent validity were not meaningful when formative indicators were involved. Nonetheless, the Total Variance Explained and the Cronbach's alphas found in this study confirmed that the constructs' measures as valid and reliable, respectively.

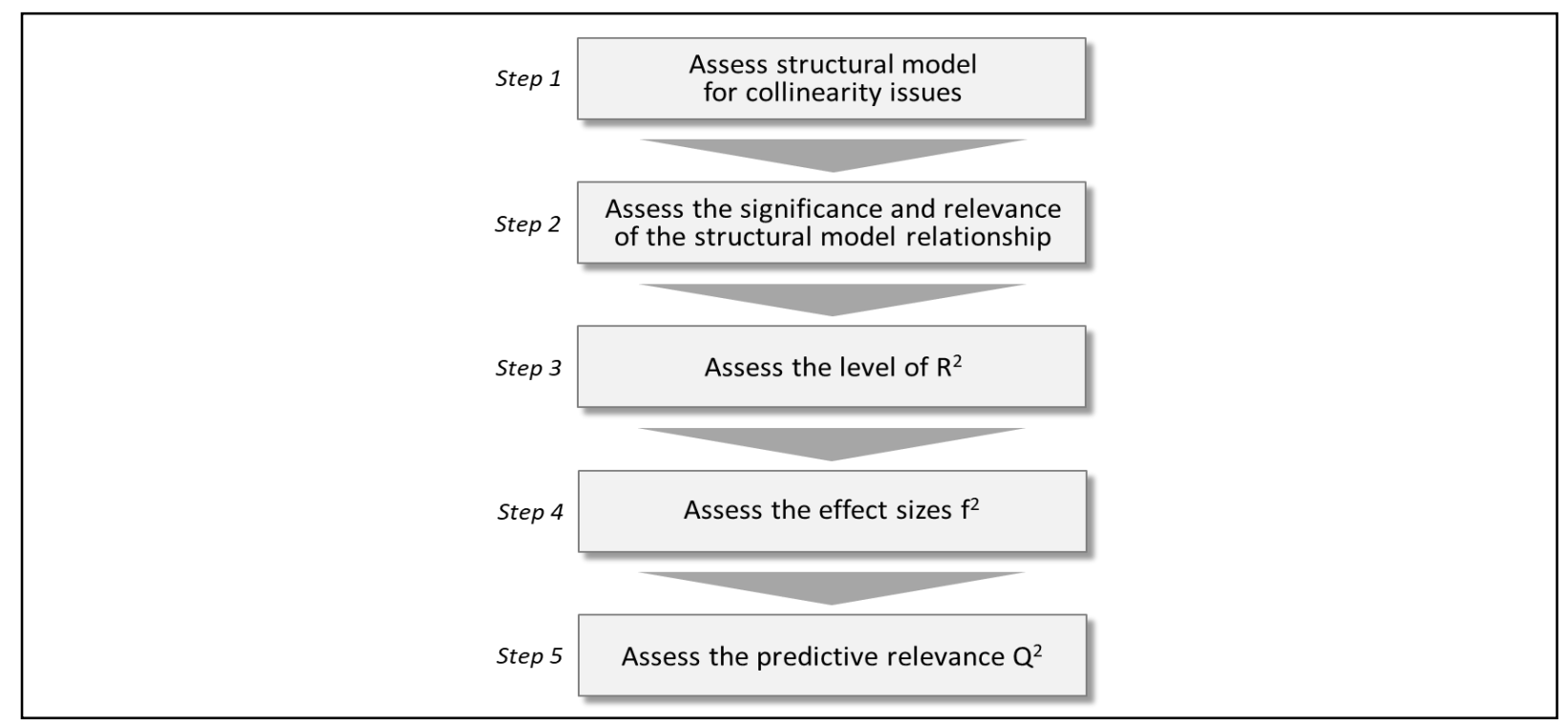

Figure 4. Structural Model Assessment Procedure (Hair et al. 2011)

The structural model shown in Figure 3 was used to examine the model's predictive capabilities and the relationships between the constructs. In doing so, Hair et al. (2011) suggested the systematic approach shown in Figure 4 for the assessment of the structural model results with formative measurement models.

Variance Inflation Factors (VIF) were checked to describe how much multicollinearity (correlation between predictors) existed. Similar to the assessment of formative measurement model indicators, the study considered VIF above 5.0 in the predictor constructs as indicative of collinearity that was too high (Hair et al.2011). The study found that all VIF values in both the inner and outer models were well below the threshold of 5.0. This indicated that there was no collinearity problem with the data.

Toobtainestimatesforthestructuralmodelrelationships (i.e. pathcoefficients), thestudy examined the significance of the path coefficients by using bootstrapping and then examined the sizes of the path coefficients. SmartPLS Manual accessed from http://www.smartpls.de/ documentation/ states that PLS-SEM does not assume that the data is normally distributed, which implies that parametric significance tests (e.g., as used in regression analyses) cannot be 


\section{Volume : 6 Nomor : 1 Maret 2021}

applied to test whether coefficients such as outer weights, outer loadings and path coefficients are significant. Instead, PLS-SEM relies on a nonparametric bootstrap procedure to test the significance of estimated path coefficients in PLS-SEM. A T-statistics of larger than 1.96 was considered significant for a two-tailed test (Hair et al., 2011). With the significance of the model's path coefficients of 2.915, 2.247, and 1.980, respectively for Engagement, Enablement, and Empowerment, the results indicated that all paths were statistically significant.

Furthermore, bootstrapping was also run to examine the significance of outer weights and outer loadings of the indicators of each latent construct. The study found that five drivers of engagement (VISN, PASN, TRUS, PCAP, GROW), two drivers of enablement (WENV, DATS), and three drivers of empowerment (ROLE, PSYC, TLED) were statistically significant. The others were below the threshold two-tailed test T-statistics of 1.96, and thus, it was necessary to check the statistical significance of their outer loadings. An indicator is removed only if both of its outer weight and outer loading are not statistically significant (Wong 2013). Looking at the T-statistics of the outer loadings of the drivers, the study indicated all drivers of engagement, four drivers of enablement (WENV, WPRO, LERN,DATS), and three drivers of empowerment (ROLE,PSYC,TLED) were considered significant.

After examining the statistical significance of relationships, it was important to assess the $\mathrm{R}^{2}$ measure, a statistical measure of how well the regression line approximates the real data points.Because the goal of the prediction-oriented PLS-SEM approach is to explain the endogenous latent variable's variance, the key target constructs' level of $\mathrm{R}^{2}$ should be high. As a rule of thumb, Hair et al. (2011) suggested that $\mathrm{R}^{2}$ values of $0.75,0.50$, or 0.25 for endogenous latent variables in the structural model can be described as substantial, moderate, or weak, respectively. The study found $\mathrm{R}^{2}$ value of 0.935 , which can be categorized as strong.

The next step that Hair et al. (2011) suggested in structural model assessment procedure was to assess the effect sizes or effect strengths, $\mathrm{f}^{2}$. The $\mathrm{f}^{2}$ relies on the change in the $\mathrm{R}^{2}$, rather than on the magnitude or significance of the path coefficient. Itshows how much an exogenous latent variable contributes to an endogenous latent variable's $R^{2}$ value. By convention, $\mathrm{f}^{2}$ of $0.02,0.15$, and 0.35 are respectively termed small effect size, medium effect size, and large effect size (Cohen 1988) of the latent exogenous variables (predictor variables) on the latent endogenous variable in the model. The study found $\mathrm{f}^{2}$ values of $0.842,0.802$, and 0.753 , respectively for engagement, enablement, and empowerment. These results of $\mathrm{R}^{2}$ and $\mathrm{f}^{2}$ indicate that strong and significant relationships existed between the exogenous latent constructs (engagement, enablement, and empowerment) and the endogenous latent construct (employee excellence). The relationship could be considered as having large effect sizes. 
Finally, as the last step in the structural model assessment procedure suggested by Hair et al. (2011), the study assessed the predictive relevance, $\mathrm{Q}^{2}$, of the model. The $\mathrm{Q}^{2}$ indicated the model's capability to predict. The predominant measure of predictive relevance was the StoneGeisser's Q2 (Geisser 1974; Stone 1974), which postulated that the model had to be able to adequately predict each endogenous latent construct's indicators. The $\mathrm{Q}^{2}$ value was obtained from a blindfolding procedure in PLS-SEM.The study found that $\mathrm{Q}^{2}$ of the model's endogenous construct was larger than zero, which indicated that the model exhibited predictive relevance.

As seen in Figure 5, the results for the structural model indicate that the coefficient of determination, $\mathrm{R}^{2}$, was 0.935 for the endogenous latent variable, Employee Excellence. This means that the three exogenous latent variables (Engagement, Enablement, and Empowerment) substantially explained $93.5 \%$ of the variance in Employee Excellence. Looking at the path coefficients, the inner model also suggested that Engagement and Enablement had similarly strong effect on Employee Excellence, while Empowerment had moderate effect on Employee Excellence. The hypothesized path relationships between Engagement, Enablement, and Empowerment were all statistically significant. Thus, it can be said that Engagement and Enablement were both strong predictors of Employee Excellence, while Empowerment moderately predicted Employee Excellence.

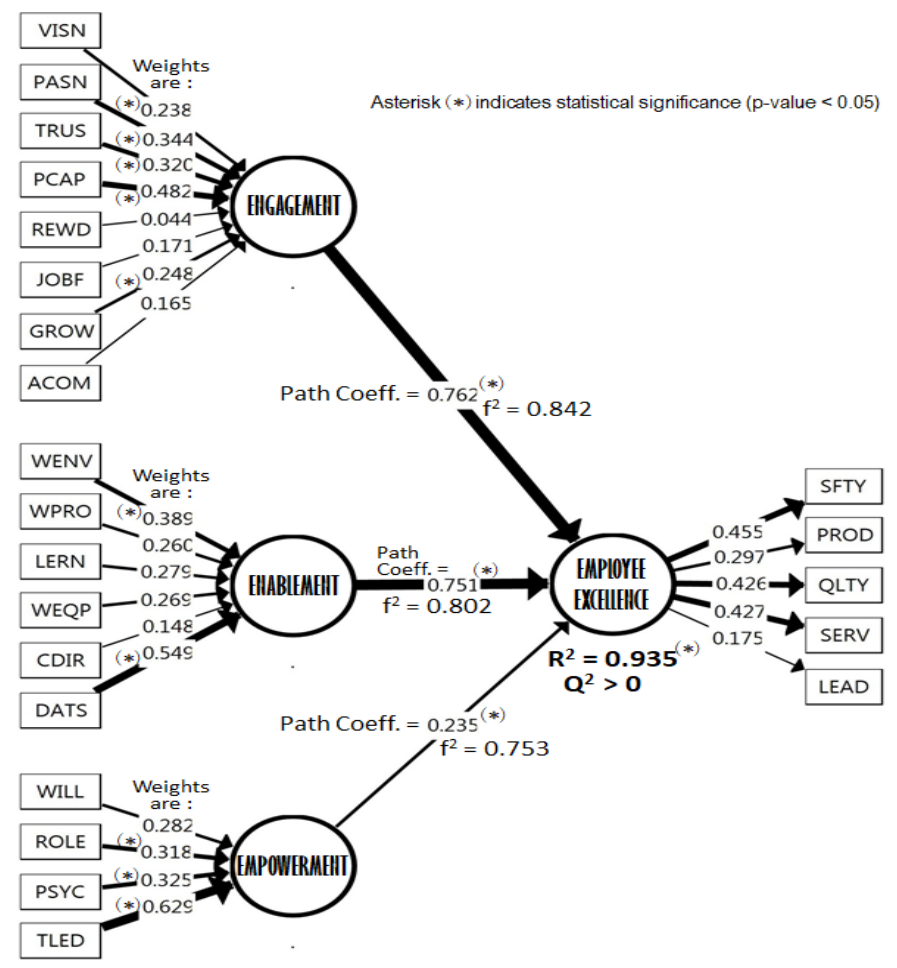

Figure 5. PLS-SEM Results of the Model 
This result showed that the driver PCAP (psychological capital) had the largest weight among all the drivers of Employee Engagement, the driver DATS (infrastructure for data sharing) had the largest weight among all the drivers of Employee Enablement, and the driver TLED (transformational leadership) had the largest weight among all the drivers of Employee Empowerment. All the weights mentioned above were found to be statistically significant.

As a furtherance of the data analysis, this study also assessed how the exogenous constructs affected the individual manifests of the endogenous construct. This was done to study which construct (among Engagement, Enablement, and Empowerment) was the most important predictor for each of the reflective manifests of employee excellence. The researcher wanted to learn which construct was the most important predictor for safety, for example. Table 3 shows the result of the study.

Table 3. Path Coefficients and Effect Sizes of Exogenous Constructs on Each Endogenous Reflective Manifests

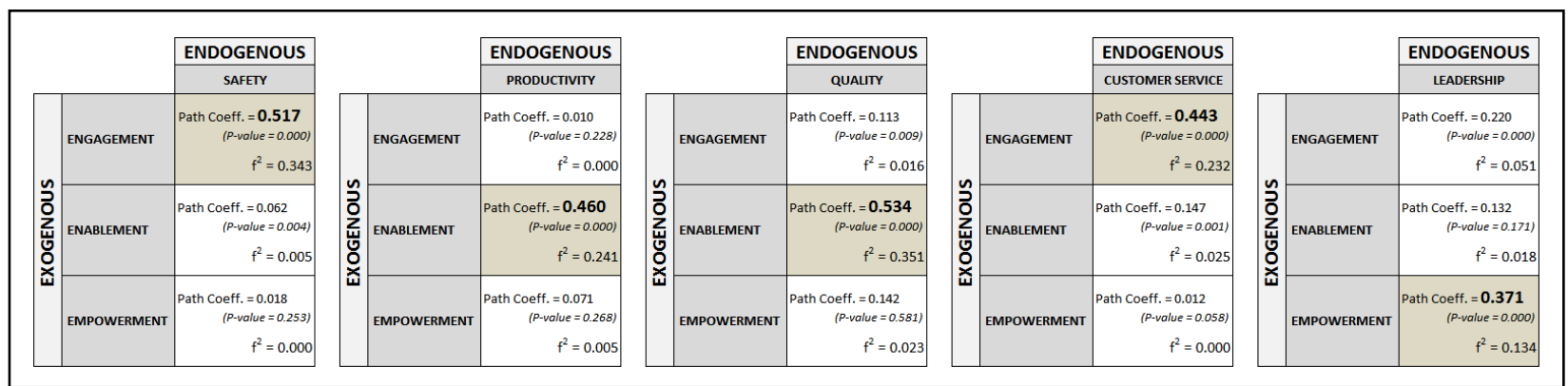

The relative importance of the exogeneous latent constructs in predicting the manifest of the dependent construct, as shown in Table 3, indicated that there was one most important predictor for each of the manifests of Employee Excellence.The study found that Engagement, Enablement and Empowerment have each relatively dissimilar strength when jointly affecting each of the reflective manifests of Employee Excellence. Table 3 shows that Safety was largely affected by Employee Engagement, Productivity was largely affected by Employee Enablement, Quality was largely affected by Employee Enablement, Customer Service was largely affected by Employee Engagement, and Leadership was largely affected by Employee Empowerment.

The above results empirically showed that employee engagement, enablement, and empowerment altogether had positive and significant effect on employee excellence. Each reflective indicator of Employee Excellence had a dominant predictor construct, which was either Engagement, Enablement, or Empowerment. These results can provide strategic prioritizationonmanagerialactionsinbuildingemployeexcellencebasedon3E: Engagement, Enablement, Empowerment. Figure 6 illustrates the 3E-based employee excellence, with the 
corresponding dominant predictor construct based on the results shown in Table 3.

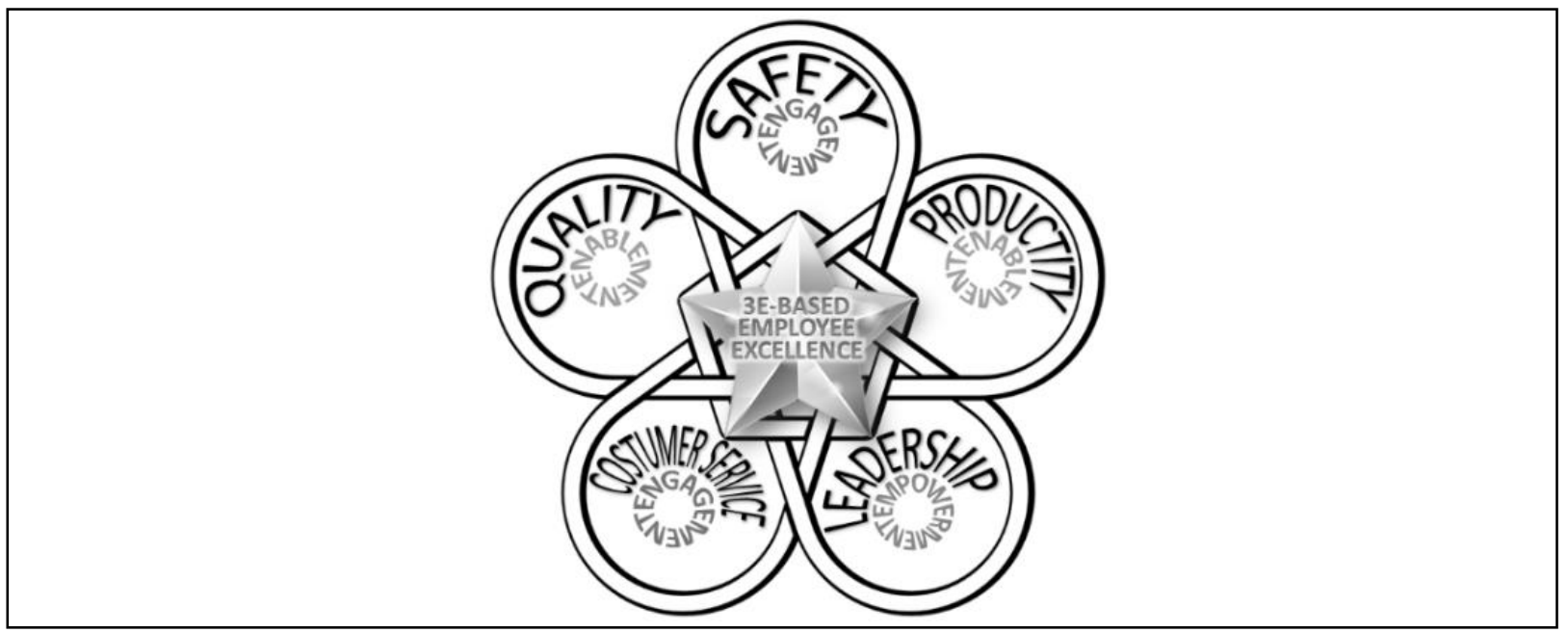

Figure 6. 3E-based Employee Excellence

This research found that employee excellence in Safety was very much affected by how engaged the employee is. Employee engagement is about what is in one's heart, willingness, commitment and efforts. Safety is about commitment. In building excellence in safety, organization should prioritize in building commitment, in touching people's heart. Enabling employees through safety training or by providing safety equipment are indeed importantand should be continuously improved.Strategic actions on building excellence on safety should be prioritized on the key driver of employee engagement, which is Psychological Capital. Organizations should direct their strategic programs toward building hope among their people by formulating safety improvement plans and continuously communicating them and their progress to the employees. By knowing what the organization is doing with regards to safety, people in the organization would be hopeful about their safety at work. Luthans et al. (2005) pointed out that those who are hopeful are likely to be motivated and more confident in taking on a task, which would result in excellent performance.

This research also found that employee excellence in Productivity was very much affected by how enabled the employee is. The study also showed that this was also true for employee excellence in Quality. Employee enablement is about fostering capability, about provision of work necessities and work environment. Excellence in productivity and quality comes from excellence in solving problems at work and sustaining the solutions. Problems occur everyday in the manufacturing production floor, and thus, it is critical to enable the employees to solve their local problems to improve their manufacturing line performance.

Strategic actions on building excellence on productivity and quality should be prioritized 
on the key driver of employee enablement, which was Infrastructure for Data Sharing. Further follow-ups with respondents revealed that "infrastructure for data sharing" implied the efforts of capturing, sharing, and effectively using organizational knowledge. This suggested that the key driver of employee enablement was Knowledge Management. Darroch (2003) defines knowledge management as: “...the process that creates or locates knowledge and manages the dissemination and use of knowledge within and between organizations." In enabling employees, management should allocate resources for employees to store their knowledge into a shared knowledge repository, such as a database, as well as to retrieve knowledge they need that other individuals have provided to the repository. In addition, management can also facilitate and encourage employees to share their knowledge directly with other employees through periodic sharing sessionsand place the shared contents in the repository.

This research further found that employee excellence in Customer Service was very much affected by how engaged the employee was. Giving excellent service is about doing it with one's heart. Customer service is about providing solutions to the customer. Therefore, it requires profound understanding of the customer's needs, listening for and resolving any issues or concerns from the customers. To encourage employees to listen to the customers, management needs to show that they listen wholeheartedly to their employees.Management needs to institutionalize internal communication functions, with scheduled and structured "chitchat" sessions. This is a key stage of ensuring employee engagement to help deliver a positive customer experience.

Lastly, this research also found that employee excellence in Leadership was very much affected by how empowered the employee was. Employee empowerment is all about what is entrusted to one's capability. Strategic actions on building excellence on leadership should then be prioritized on the key driver of employee engagement, which is transformational leadership. A transformational leader is basically an agent of change, serving as a catalyst of change, not a controller of change (Bass and Avolio 1994). Leadership was found to have much greater impact on employee effectiveness, even when compared with work discipline (Cahyadi, 2016).

In summary, employee excellence which was manifested in the five reflective indicators of safety, productivity, quality, customer service, and leadership required all the three constructs of predictors (employee engagement, enablement, and empowerment) to bring about excellent stars among the people in an organization. As illustrated in Figure 7, missing one of the predictor constructs would result in a star employee who was not as intended. An employee might well be engaged and enabled but could be powerless when and if the employee was not empowered with authority and responsibility to solve problems and make decisions. Likewise, 
although an employee was engaged and empower, she/he would be disabled when and if she/he was not provided with adequate work necessities and supportive working environment. Without engagement, an employee who was well equipped and provided with supportive working environment and was given adequate authority and responsibility would just be as well disengaged from her/his work. The researcher argues that disengaged employees, disabled employees, or powerless employees will produce inadequate performance.

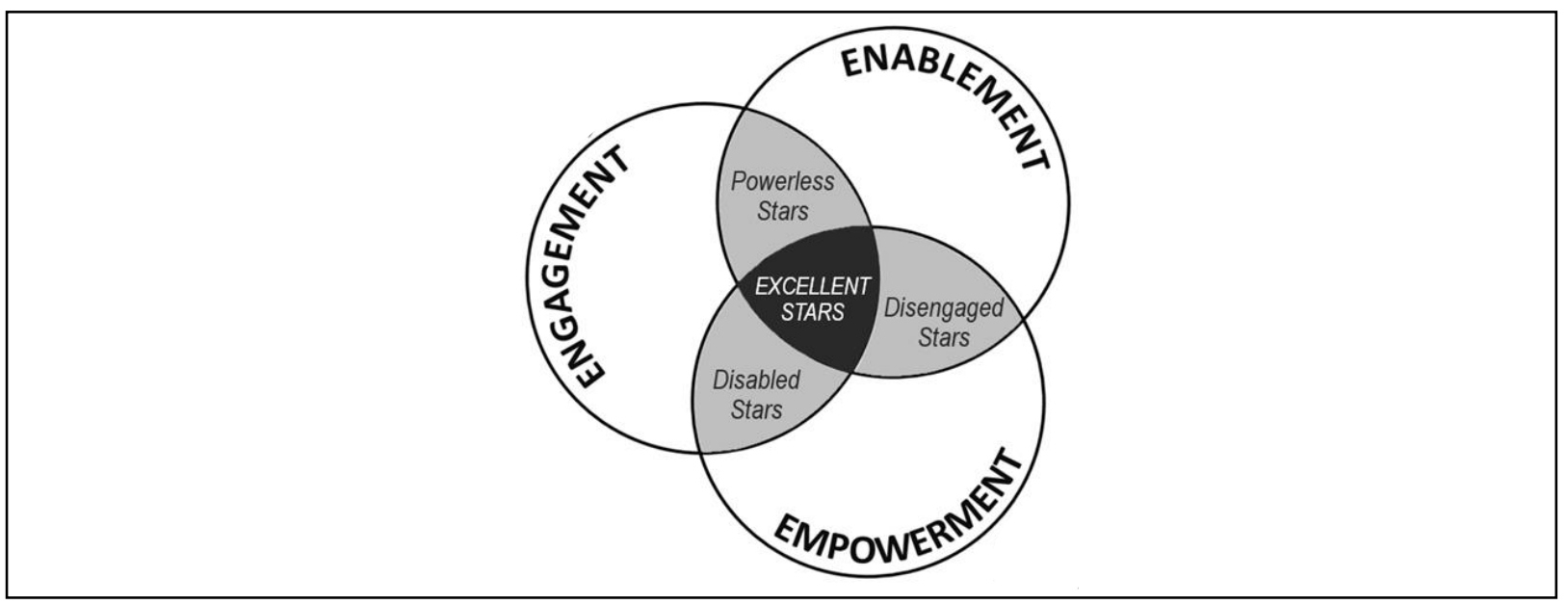

Figure 7. 3E-based Excellent Stars

\section{E. CONCLUSIONS AND RECOMMENDATIONS}

The study of employee excellence is an important issue in the current fiercely dynamic business environment, where organizations must excel to succeed and survive. Excellence through people is an enduring excellence for an organization. This study provides a roadmap to building the excellence in the people of the organizations.

This study has explored quantitatively the drivers of employee engagement, enablement, and empowerment for maximizing employee excellence. It focused its scope on select manufacturing organizations in Indonesia. The study result showed how employee excellence related with employee engagement, enablement, and empowerment.The study pointed out that each manifest indicator of employee excellence is affected dominantly by different predictor construct. Therefore, building employee excellence would require building the three predictor constructs altogether. Management should give attention to building employee engagement, enablement, and empowerment altogether in order to bring about employee excellence.

The study has both theoretical and practical implications. Theoretically, this research contributed a theory development to the existing stream. The 3E-based employee excellence was a key contribution from this research. The research found the key driver of each of the 
predictor constructs, and suggested ways to grow the key driverstofurther the development of employee excellence. Practically, this research provided management with an empirical basis for prioritizing strategy on actions to effectively affect employee engagement, enablement, and empowerment.

Further use of the results of the study should be applied with care, for they might not be generalizable to other types of organizations and might give different results when applied to different level of employees. This "gap", on the other hand, may suggest topics for future research to deep dive the extent of the 3E-based Employee Excellence model applicability.Therefore, a recommendation for future research to fill in the gap would be to reproduce this study in different type of organizations or industries, or even countries, to investigate the influence of cross-border cultural differences.

\section{ACKNOWLEDGEMENT}

The researcher would like to dedicate this research paper to the late $\mathrm{Hj}$. Tien Pangastuti, the researcher's utmost-loved soulmate, for her endless love and supports during the last period of her life motivating and cheering up the progressionof this research work.

\section{REFERENCES}

\section{Books}

Avolio, B. and Luthans, F. 2006. The high impact leader: Moments matter in accelerating authentic leadership development. New York: McGraw-Hill.

Coakes, S. J., and Steed, L. G. 2007. SPSS: Analysis without anguish: version 14.0 for Windows. Brisbane: John Wiley \& Sons Australia Ltd.

Cohen, J. 1988. Statistical power analysis for the behavioral sciences (second ed.). Hillsdale, NJ: Lawrence Erlbaum Associates.

Hair, J.F., Black, W.C., Babin, B.J., and Anderson, R.E. 2010. Multivariate data analysis. Seventh Edition. Upper Saddle River, New Jersey: Prentice Hall.

Kline, R. B. 2005. Principles and practice of Structural Equation Modeling. 2nd edition. New York: Guilford Press.

Leech, N.L., Barret, K.C., and Morgan, G.A. 2005. SPSS for intermediate statistics: Use and interpretation. 2nd Edition. New Jersey: Lawrence Erlbaum Associates, Publishers. 
Liker, J.K. and Meier, D.P. 2007. The Toyota talent: Developing your people the Toyota way. New York: McGraw-Hill.

Luthans, F., Yousseff, C.M. and Avolio, B.J. 2007. Psychological capital: Developing the human competitive edge. Oxford: Oxford University Press.

Newman, D.A., Joseph, D.L., and Hulin, C.L. 2010. Job Attitudes and Employee Engagement: Considering the Attitude 'A-Factor, inHandbook of Employee Engagement, 43-61.

Osborne, D. and Plastrik, P. 2000. Employee Empowerment: Giving Frontline Employees the Power to Improve Results, The Reinventor's Fieldbook, 5, 103-142.

Senge, P.M. 2006. The fifth discipline: The art and practice of the learning organization. 2nd Edition, London: Century.

Senge, P.M. 2015. "Leading learning organizations: The bold, the powerful, and the invisible," $A$ shortened version of $P$. Senge, Leading learning organizations (MIT Center for Organizational Learning Research Monograph), Cambridge, Mass.: MIT Center for Organizational Learning.

Tabachnick, B.G. and Fidell, L.S. 1996. Using multivariate statistics. 3rd Edition. New York: Harper Collins Publishers.

Wiley, J.W., Kowske, B.J., and Herman, A.E. 2010. Developing and Validating A Global Model of Employee Engagement, in Handbook of Employee Engagement, 351-362.

Wilson, B. 2007. Employee Engagement: What Managers Need to Know? Marsh \& McLennan Companies.

Wold, H. 1981. "The fix-point approach to interdependent systems: Review and current outlook." In: H. Wold (ed.), The Fix-Point Approach to Interdependent Systems, North-Holland, Amsterdam.

\section{Journals}

Arquisola, M.J. and Ahlisa, S.U.W. 2019. "Do Learning and Development Interventions Motivate Employees at PT Danone Indonesia? Applying McClelland's Theory of Motivation to FMCG Industries," FIRM Journal of Management Studies, 4(2):160-176, doi: 10.33021/firm.v4i2.780

Avey, J.B., Hughes, L.W., Norman, S.M., and Luthans, K.W. 2007. The Role of Positive Capacities, Transformational Leadership and Empowerment in Combating Employee Negativity, Working Paper.

Avolio, B.J., Bass, B.M., and Jung, D. 1999. "Re-examining the components of transformational and transaction using the multi-factor leadership questionnaire," Journal of Occupational and Organizational Psychology 72: 441-462.

Bass, B.M. and Avolio, B.J. 1994.“Transformational leadership and organizational culture,"International Journal of Public Administration 17 (3/4): 541-552.

Binhu, P. H. 2012. Role of Job Related Factors in Engaging Employees,Sumedha Journal of Management, 1(3): 56-68.

Cahyadi, N. 2016. "Pengaruh Kepemimpinan dan Disiplin Kerja terhadap Efektivitas Kerja KaryawanPT Erza Nusa Indonesia Gresik," FIRM Journal of Management Studies, 1(2), doi:10.33021/firm.v1i2.105 
Chin, W.W, and Newsted, P.R. 1999. "Structural Equation Modeling analysis with small samples using Partial Least Squares," In Statistical strategies for small sample research, Hoyle, R. H., ed. Thousand Oaks: Sage, 307-342.

Coffman, C. and Harter, J. 1999. "A hard look at soft numbers," Linking Attitudes to Outcome, A Gallup Report.

Darroch, J. 2003. "Developing a measure of knowledge management behaviors and practices," Journal of Knowledge Management 7 (5): 41-54.

Edward, J.R., and Bagozzi, R.P. 2000. "On the nature and direction of relationships between constructs and measures," Psychological Methods 5 (2): 155-174.

Geisser, S. 1974. "A predictive approach to the random effects model," Biometrika 61(1): 101107.

Hair, J.F., Ringle, C.M., and Sarstedt, M. 2011. "PLS-SEM: Indeed a silver bullet," Journal of Marketing Theory and Practice 19 (2): 139-152, doi: dx.doi.org/10.2753/MTP10696679190202

Ismail, A., Mohamed, H.A., Sulaiman, A.Z., Mohamad, M.H., and Yusuf, M.H.2011. “An Empirical Study of the Relationship between Transformational Leadership, Empowerment and Organizational Commitment". Business \& Economics Research Journal, Vol.2 No.1, pp.89-107.

Luthans, F., Avolio, B. J., Walumbwa, F. O., and Li, W. 2005. "The psychological capital of Chinese workers: Exploring the relationship with performance," Management and Organization Review 1: 247-269.

Permana, I., Tjakraatmadja, J.H., Larso, D., and Wicaksono, A. 2015. "Determining relativeimportance of the drivers of employee engagement, enablement, and empowerment using analytic hierarchy process for developing sustainable employee excellence in manufacturing environment in Indonesia," Mediterranean Journal of Social Sciences 6 (3): 600-609, doi:10.5901/mjss.2015.v6n3s2p600

Schaufeli, W.B., Bakker, A.B., and Salanova, M. 2006. The Measurement of Work Engagement with A Short Questionnaire: A Cross-national Study,Educational and Psychological Measurement, 66(4), 701-716.

Shahnawaz, M.G. and Jafri, M.H. 2009. Psychological Capital as Predictors of Organizational Commitment and Organizational Citizenship Behavior, Journal of the Indian Academy of Applied Psychology, 35(2), 78-84.

Stone, M. 1974. "Cross-validatory choice and assessment of statistical predictions," Journal of the Royal Statistical Society 36 (2): 111-147.

Westland, J. C. and See, W.K. 2007. "The Short-run price- performance dynamics of microcomputer technologies," Research Policy 36 (5): 591-604. 
Wong, K.K. 2013. "Partial Least Squares Structural Equation Modeling (PLS-SEM) techniques using SmartPLS," Marketing Bulletin 24 (1): 1-32

Wright, Winter (2008): Ready, Willing and Enabled: A Formula for Performance, The Economist Intelligence Unit.

\section{Websites}

Bido, D. 2006. SmartPLS Forums, from http://www.smartpls.de/, accessed on 5 August 2019

SmartPLS Manual, from http://www.smartpls.de/documentation/, accessed on 20 September 2019 